Article

\title{
Composite Building Materials: Thermal and Mechanical Performances of Samples Realized with Hay and Natural Resins
}

\author{
Maria La Gennusa ${ }^{1, *}$, Pere Llorach-Massana ${ }^{2}$, Juan Ignacio Montero ${ }^{3}$, Francisco Javier Peña ${ }^{4}$, \\ Joan Rieradevall ${ }^{2,5}$, Patrizia Ferrante ${ }^{1}$, Gianluca Scaccianoce ${ }^{1}$ and Giancarlo Sorrentino ${ }^{1}$ \\ 1 Dipartimento di Energia, Ingegneria dell'Informazione e modelli Matematici (DEIM), \\ Università degli Studi di Palermo, Viale delle Scienze, 90128 Palermo, Italy; patrizia.ferrante@unipa.it (P.F.); \\ gianluca.scaccianoce@unipa.it (G.S.); giancarlo.sorrentino@unipa.it (G.S.) \\ 2 Sostenipra Research Group (SGR 01412), Institute of Environmental Sciences and Technology \\ (ICTA; Unidad de excelencia «María de Maeztu» (MDM-2015-0552)), Z Building, \\ Universitat Autònoma de Barcelona (UAB), Campus UAB, 08193 Bellaterra, Barcelona, Spain; \\ pere.llorach@uab.cat (P.L.-M.); joan.rieradevall@uab.cat (J.R.I.P.) \\ 3 Institute of Food and Agricultural Research (IRTA), Carretera de Cabrils, km 2, 08348 Barcelona, Spain; \\ juanignacio.montero@irta.cat \\ 4 ELISAVA Barcelona School of Design and Engineering, La Rambla 30-32, 08002 Barcelona, Spain; \\ jpenya@elisava.net \\ 5 Department of Chemical Engineering, Biological and Environmental, School of Engineering, Building Q, \\ Universitat Autònoma de Barcelona (UAB), 08193 Bellaterra, Barcelona, Spain \\ * Correspondence: maria.lagennusa@unipa.it; Tel.: +39-091-2386-1949
}

Academic Editors: Francesco Asdrubali and Pietro Buzzini

Received: 31 October 2016; Accepted: 27 February 2017; Published: 3 March 2017

\begin{abstract}
Recent years have seen an increasing public interest in issues related to energy saving and environmental pollution reduction in the building sector. As a result, many directives have been issued, the most important being the Directive 2010/31/EU (EPBD Recast) on the energy performance of buildings, which requires that "Member States shall ensure that by 31 December 2020 all new buildings are nearly zero-energy buildings". This goal can be obtained not only by reducing energy demand for heating and cooling, but also, for example, by improving building envelope performances. In this work, a first analysis of the thermal and structural behaviour of a biocomposite material, constituted by a natural resin (rosin) and vegetal fibres (hay), has been performed, with particular attention to the share of fibres and the granulometry in the mixture. The biocomposite has shown both good insulation properties and mechanical resistance. However, the results show that further analyses should be performed on the optimisation of the samples' preparation process.
\end{abstract}

Keywords: energy building; natural materials; biocomposite; thermal and mechanical properties

\section{Introduction}

Recent years have seen an increasing public interest in issues related to energy saving and environmental pollution reduction in the building sector. As a result, many directives have been issued, the most important being the Directive 2010/31/EU (EPBD Recast) [1] on the energy performance of buildings, which requires that "Member States shall ensure that by 31 December 2020 all new buildings are nearly zero-energy buildings". This goal can be obtained not only by reducing energy demand for heating and cooling, but also, for example, by improving building envelope performances. Thermal insulation is a major contributor as the first practical and logical step towards achieving energy efficiency, especially in envelope-load-dominated buildings located in sites with harsh climatic 
conditions. The new approach to energy-efficient design also includes development and use of natural and local building materials - and bio-based composites among them — with the main aim of reducing the global impact of buildings in a life cycle perspective.

Recently, there has been a rapid growth in research and innovation in the natural fibre composite (NFC) area. Interest is warranted due to the advantages of these materials compared to others-such as synthetic fibre composites-including low environmental impact and low cost, which supports their potential across a wide range of applications.

Therefore, the demand of ecological building materials is rapidly growing in the market, particularly regarding insulating materials from renewable resources. Many researchers have approached the study of such natural materials, especially investigating their thermal insulating and mechanical properties. The most studied materials are jute [2-4], cork [5], corncob [6,7], hay [8], sugarcane [8,9], wood wool and rock wool [10], cellulose loose-fill [11], flax [2,12-15], straw bales [16-18], coconut [19-22], and hemp [2,13-15,23-32]. Much effort has gone into increasing their mechanical performance to extend the capabilities and applications of this group of materials. Mechanical performances of some natural fibre composites are summarised in Table 1.

Table 1. Mix of natural fibres and resin and their mechanical characteristics.

\begin{tabular}{|c|c|c|c|c|c|c|c|c|}
\hline Fibre & Orientation & Matrix & $\begin{array}{c}\text { Fibre } \\
\text { Content } \\
(\%)\end{array}$ & $\begin{array}{c}\text { Tensile } \\
\text { Strength } \\
\text { (MPa) }\end{array}$ & $\begin{array}{l}\text { Young's } \\
\text { Modulus } \\
\text { (GPa) }\end{array}$ & $\begin{array}{c}\text { Flexural } \\
\text { Strength } \\
(\mathrm{MPa})\end{array}$ & $\begin{array}{c}\text { Flexural } \\
\text { Modulus } \\
\text { (GPa) }\end{array}$ & Reference \\
\hline Hay & random & Rosin & $50 / 70$ & $6 / 13$ & $0.4 / 1$ & 6 & & [This study] \\
\hline Alfa & aligned & UP & 48 & 149 & 12 & & & [33] \\
\hline Cellulose & continuous & Bio-Epoxy & & 92 & 9 & 727 & 27 & [34] \\
\hline Cordenka $^{\mathrm{a}}$ & - & PA & 30 & 120 & 6 & & & [35] \\
\hline Cordenka ${ }^{a}$ & - & PP & 42 & 90 & 4 & & & [36] \\
\hline Cordenka $^{\mathrm{a}}$ & - & PLA & 25 & 108 & 4 & & & [36] \\
\hline Flax & - & $\mathrm{PP}$ & 30 & & & $74^{\mathrm{b}}$ & & [37] \\
\hline Flax & - & PP & 30 & 52 & 5 & 60 & 5 & [38] \\
\hline Flax & aligned & Epoxy & $46 / 54$ & $280 / 279$ & $35 / 39$ & 223 & & [39] \\
\hline Flax & aligned & Epoxy & 37 & 132 & 15 & & & [40] \\
\hline Flax & aligned & $\mathrm{PP}$ & 50 & 40 & 7 & & & [41] \\
\hline Flax & aligned & PP & 39 & & & 212 & 23 & [42] \\
\hline Flax & random & UP & 39 & 61 & 6 & 91 & 5 & [43] \\
\hline Flax & random & PLA & 30 & 100 & 8 & & & [44] \\
\hline Flax & random & PLLA & 30 & 99 & 9 & & & [44] \\
\hline Flax & short-nonwoven & Shellac & 49 & 109 & 10 & & & [45] \\
\hline Flax & woven & Epoxy & 50 & 104 & 10 & & & {$[46]$} \\
\hline Flax hackled & aligned & Epoxy & 28 & & & 182 & 20 & [47] \\
\hline Flax sliver & aligned & UP & 58 & 304 & 30 & & & [48] \\
\hline Flax sliver & aligned & $\mathrm{PP}$ & 44 & & & 146 & 15 & [49] \\
\hline Flax sliver & biaxial/major axis & Epoxy & 46 & 200 & 17 & 194 & 13 & [50] \\
\hline Flax yarn & aligned & Epoxy & 45 & & & 311 & 25 & [51] \\
\hline Flax yarn & aligned & Epoxy & 31 & 160 & 15 & 190 & 15 & {$[47]$} \\
\hline Flax yarn & aligned & Epoxy & 45 & 133 & 28 & 218 & 18 & [51] \\
\hline Flax yarn & aligned & VE & 24 & 248 & 24 & & & [47] \\
\hline Flax yarn & aligned & UP & 34 & 143 & 14 & 198 & 17 & [47] \\
\hline Flax yarn & aligned & PP & 72 & 321 & 29 & & & [52] \\
\hline Flax yarn & aligned & $\mathrm{PP}$ & 30 & $89 / 70$ & $7 / 6$ & & & [53] \\
\hline Flax yarn & woven & VE & 35 & 111 & 10 & 128 & 10 & [47] \\
\hline Harakeke & aligned & Epoxy & $50 / 55$ & 223 & 17 & & 14 & [54] \\
\hline Harakeke & aligned & Epoxy & 52 & 211 & 15 & & & [55] \\
\hline Harakeke & DSF & Epoxy & 45 & 136 & 11 & 155 & 10 & [56] \\
\hline Harakeke & DSF & PLA & 30 & 102 & 8 & & & [56] \\
\hline Harakeke & random & Epoxy & 45 & & & 188 & 9 & [57] \\
\hline Hemp & - & PP & 40 & 52 & 4 & 86 & 4 & [58] \\
\hline Hemp & aligned & Epoxy & 65 & 165 & 17 & 180 & 9 & [59] \\
\hline Hemp & aligned & $\mathrm{PP}$ & 46 & & & 127 & 11 & [49] \\
\hline Hemp & aligned & PLA & 30 & 77 & 10 & 101 & 7 & [60] \\
\hline Hemp & biaxial & PLA & 45 & 62 & 7 & 124 & 9 & [61] \\
\hline Hemp & carded & PLA & 30 & 83 & 11 & 143 & 7 & [62] \\
\hline Hemp & DSF & Epoxy & 50 & 105 & 9 & 126 & 8 & [56] \\
\hline Hemp & DSF & Epoxy & 65 & 113 & 18 & 145 & 10 & [59] \\
\hline Hemp & DSF & PLA & 25 & 87 & 9 & & & [56] \\
\hline Hemp & random & PLA & 47 & 55 & 9 & 113 & & [63] \\
\hline
\end{tabular}


Table 1. Cont.

\begin{tabular}{|c|c|c|c|c|c|c|c|c|}
\hline Fibre & Orientation & Matrix & $\begin{array}{c}\text { Fibre } \\
\text { Content } \\
(\%)\end{array}$ & $\begin{array}{c}\text { Tensile } \\
\text { Strength } \\
\text { (MPa) }\end{array}$ & $\begin{array}{c}\text { Young's } \\
\text { Modulus } \\
\text { (GPa) }\end{array}$ & $\begin{array}{c}\text { Flexural } \\
\text { Strength } \\
(\mathrm{MPa})\end{array}$ & $\begin{array}{c}\text { Flexural } \\
\text { Modulus } \\
\text { (GPa) }\end{array}$ & Reference \\
\hline Jute & - & PP & 60 & 74 & 11 & 112 & 12 & {$[64]$} \\
\hline Jute & woven & UP & 35 & 50 & 8 & 103 & 7 & [43] \\
\hline Kenaf & aligned & PLA & 40 & 82 & 8 & 126 & 7 & [65] \\
\hline Kenaf & aligned & PHB & 40 & 70 & 6 & 101 & 7 & [65] \\
\hline Kenaf & random & $\mathrm{PP}$ & 30 & 46 & 5 & 58 & 4 & {$[66]$} \\
\hline Kenaf & aligned & PLA & 80 & 223 & 23 & 254 & 22 & [67] \\
\hline Kraft & - & $\mathrm{PP}$ & 40 & 52 & 3 & 90 & 4 & [58] \\
\hline Lyocell $^{\mathrm{a}}$ & carded & PLA & 30 & 89 & 9 & 148 & 6 & [65] \\
\hline Lyocell $^{\mathrm{a}}$ & carded & РHB & 30 & 66 & 5 & 105 & 5 & [65] \\
\hline Newsprint & - & PP & 40 & 53 & 3 & 94 & 4 & [58] \\
\hline PALF & random & UP & 30 & 53 & 2 & 80 & 3 & [68] \\
\hline Sisal & aligned & Epoxy & 73 & 410 & 6 & 320 & 27 & [69] \\
\hline Sisal & aligned & Epoxy & 77 & 330 & 10 & 290 & 22 & [69] \\
\hline Sisal & aligned & Epoxy & 48 & 211 & 20 & & & [40] \\
\hline Sisal & aligned & Epoxy & 37 & 183 & 15 & & & [40] \\
\hline Wood BKP & - & PP & 40 & 50 & 3 & 78 & 3 & [70] \\
\hline
\end{tabular}

At the University of Palermo, the group of the Laboratory for Indoor Environments and Sustainable Technologies has long been carrying out an extensive series of experiments, mostly on the use of vegetable fibres-some of them from agricultural wastes-as components of products for the building envelope. In this work, a first analysis of the thermal and structural behaviour of a biocomposite material, constituted by a natural resin (rosin) with the addition of vegetal fibres (hay), has been performed, with particular attention to the share of fibres and their granulometry in the mixture.

This research is jointly conducted by the Università degli Studi di Palermo and the Universitat Autònoma de Barcelona.

\section{Raw Materials}

Among the different natural fibres, hay has been selected to be used in this work because of its widespread presence throughout Europe and in Italy especially, where it is regularly cultivated. As far as the binder is concerned, the choice has fallen on a natural resin. In particular, the most common natural resin is rosin, which is extracted from conifers that are also largely widespread throughout Europe and Italy. Therefore, the components of the biocomposite realised are two natural materials that can be easily found on the local market, are cheap, and that have an added value by means of a an additional use as insulating material in the building sector.

\subsection{Hay}

Hay is grass or herbaceous plant that have been cut and dried. In this paper, Hedysarum coronarium (commonly named sulla), an autochthon spontaneous plant widely spread in Italy, has been used. Sulla is a leguminous perennial plant, with a life span of 2 years. It is very heat- and drought-resistant. It has stems from $0.8 \mathrm{~m}$ to $1.5 \mathrm{~m}$ tall. Its thermal conductivity is equal to $0.052 \mathrm{~W} / \mathrm{mK}$ [71].

\subsection{Rosin}

Rosin, also called colophony or Greek pitch, owes its name to ancient town of Colofone, between Izmir and Efes, in Asia Minor. It is a vegetal resin, yellow, vitreous, very fragile, and easy to pulverise. It is obtained from terpene, which is a liquid resin pouring from incisions performed on conifer trunks.

By distilling terpene, two different fractions can be obtained: a volatile, liquid fraction, turpentine $(20 \%)$, and a solid fraction, rosin $(80 \%)$. Rosin chemically consists of $10 \%$ inert material and $90 \%$ 
resin acids: in particular, $90 \%$ abietic acid $\left(\mathrm{C}_{19} \mathrm{H}_{29} \mathrm{COOH}\right)$ and $10 \%$ a mix of dihydroabietic acid $\left(\mathrm{C}_{19} \mathrm{H}_{31} \mathrm{COOH}\right)$ and dehydroabietic acid $\left(\mathrm{C}_{19} \mathrm{H}_{27} \mathrm{COOH}\right)$.

Table 2 summarises the main physical and chemical characteristics of rosin.

Table 2. Physical and chemical characteristics of rosin [72].

\begin{tabular}{cc}
\hline Property & Values \\
\hline Density & $1.04-1.10 \mathrm{~g} / \mathrm{cm}^{3}$ \\
Thermal conductivity $\lambda$ & $0.128 \mathrm{~W} / \mathrm{mK}$ \\
Acid number & $>150$ \\
Softening point & $70{ }^{\circ} \mathrm{C}-80^{\circ} \mathrm{C}$ \\
Melting point & $60-135^{\circ} \mathrm{C}$ \\
Dropping point & $80-95^{\circ} \mathrm{C}$ \\
Ashes & $<0.031 \%$ \\
Saponification number & $170-185$ \\
Insaponifiable matter & $3 \%-8 \%$ \\
\hline
\end{tabular}

Rosin is insoluble in water; proper solvents are instead alcohol, benzene, ether, chloroform, glacial acetic acid, oils, and carbon disulphide, while by using weak solvents, like turpentine, a small amount $(<0.5 \%)$ of insoluble matter can be obtained. Finally, rosin can be melted by heating it.

\section{Experimental Procedure}

In this work, three different mixes were chosen to be investigated, that is, hay with a granulometry of $8 \mathrm{~mm}$ and $50 \%, 60 \%$, and $70 \%$ in weight of rosin. For each of the mixes, both a parallelepiped sample $(160 \times 140 \times 40 \mathrm{~mm})$ and a cylinder sample $(102 \mathrm{~mm}$ diameter, $166 \mathrm{~mm}$ height $)$ were prepared respectively for thermal and mechanical tests (Figure 1).

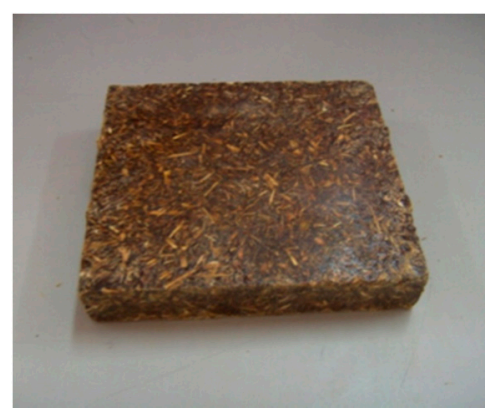

(a)

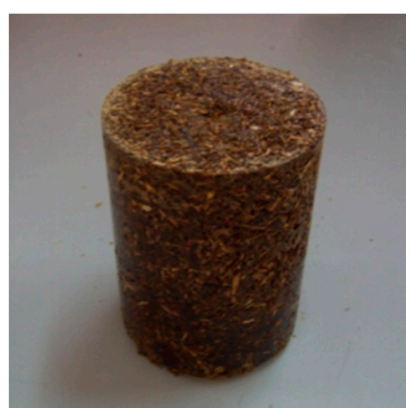

(b)

Figure 1. Hay samples (60\%) removed from the moulds: (a) parallelepiped sample; (b) cylindrical sample.

During the screening phase, a higher fibre content in the mix was tested. The increase of fibres led to the impossibility of mixing the material and to a non-homogeneous mix with many voids, so $70 \%$ hay should be considered the upper limit of the mix.

As far as the rosin is concerned, tested solvents, like turpentine, did not allow the mix to solidify, so it was melted by means of a burner.

During the preparation of the samples, larger than the ones prepared during the screening phase, some other problems arose.

One of the problems was homogeneously filling the mould with the mix, as the sudden solidification of the rosin let many voids in the mould (Figure 2). To overcome this problem, the steel moulds were preheated on a burner and, during the preparation of the samples, a heat gun was used to minimize the difference of temperature between the mould and the mix and prevent the 
sudden solidification of the mix. To minimise the voids in the mix, instead, a weight was put on the upper surface of sample, applying an overpressure equal to $7.9 \mathrm{kPa}$.

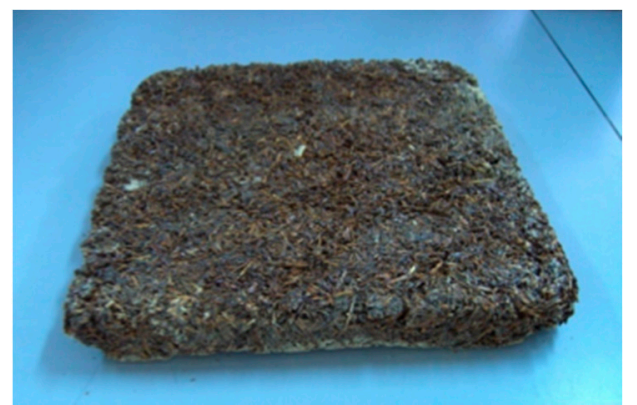

(a)

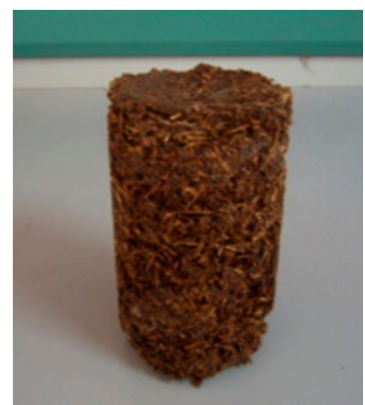

(b)

Figure 2. Samples removed from the moulds with many visible voids: (a) parallelepiped sample; (b) cylindrical sample.

Another problem has been to safely remove the samples from the moulds after the drying process. To overcome this problem, the inner surface of the mould was covered with Teflon, which is one of several commercial denominations of polytetrafluoroethylene (PTFE). PTFE is a thermoplastic polymer, with one of the lowest known coefficients of friction and a high melting point, often used to cover surfaces exposed to high temperatures without adhering or reacting. Others tested methods proved unsatisfactory, including covering the inner surface of the mould with kraft paper (the mix adhered to the paper) or directly filling the mould with the mix without covering the inner surface (the mix perfectly adhered to the surface and crushed when trying to remove it from the mould).

In Tables 3 and 4, the physical properties of the prepared samples are shown. An alphanumeric code has been assigned to each sample (e.g., "F50P") where:

- the first letter, F, stands for hay (fieno in Italian);

- the number stands for the percentage in weight of hay;

- the final letter stands for parallelepiped (P) or cylinder (C).

Table 3. Physical characteristics of the parallelepiped samples.

\begin{tabular}{|c|c|c|c|c|c|c|}
\hline Sample ID & \% Hay & $\begin{array}{c}\text { Hay } \\
\text { Granulometry } \\
(\mathrm{mm})\end{array}$ & $\begin{array}{c}\text { Dimensions } \\
(\mathrm{L} \times \mathrm{P} \times \mathrm{H}) \\
(\mathrm{mm} \times \mathrm{mm} \times \mathrm{mm})\end{array}$ & $\begin{array}{c}\text { Weight } \\
\text { (g) }\end{array}$ & $\begin{array}{l}\text { Volume } \\
\left(\mathrm{cm}^{3}\right)\end{array}$ & $\begin{array}{c}\text { Bulk } \\
\text { Density } \\
\left(\mathrm{kg} / \mathrm{m}^{3}\right)\end{array}$ \\
\hline F50P & 50 & 8 & $159 \times 139 \times 28$ & 612.3 & 619 & 989 \\
\hline F60P & 60 & 8 & $160 \times 139 \times 29$ & 613.0 & 656 & 934 \\
\hline F70P & 70 & 8 & $158 \times 140 \times 29$ & 511.5 & 647 & 791 \\
\hline
\end{tabular}

Table 4. Physical characteristics of the cylindrical samples.

\begin{tabular}{|c|c|c|c|c|c|c|}
\hline Sample ID & \% Hay & $\begin{array}{c}\text { Hay } \\
\text { Granulometry } \\
(\mathrm{mm})\end{array}$ & $\begin{array}{c}\text { Dimensions (D/H) } \\
(\mathrm{mm} / \mathrm{mm})\end{array}$ & $\begin{array}{l}\text { Weight } \\
\text { (g) }\end{array}$ & $\begin{array}{c}\text { Volume } \\
\left(\mathrm{cm}^{3}\right)\end{array}$ & $\begin{array}{c}\text { Bulk } \\
\text { Density } \\
\left(\mathrm{kg} / \mathrm{m}^{3}\right)\end{array}$ \\
\hline F50C & 50 & 8 & $100 / 157$ & 1239.5 & 120 & 1005 \\
\hline F60C & 60 & 8 & $100 / 130$ & 996 & 102 & 976 \\
\hline F70C & 70 & 8 & $100 / 112$ & 707 & 90 & 804 \\
\hline
\end{tabular}




\section{Thermal Properties}

Thermal tests have been performed on the prepared parallelepiped samples to investigate their thermal conductivity. A heat flow meter (LaserComp Fox 314) has been used for the tests in compliance with the UNI EN 12667 [73].

A ring of polystyrene has been put along the lateral side of the samples to adapt them to the heat flow meter size, minimising non-orthogonal flux between the plates. The upper and lower surfaces of the samples have been carefully smoothed by means of an orbital sander and sandpaper in order to ensure good contact with the plates, preventing any air gap.

In Table 5, the main test results are reported.

Table 5. Thermal test results.

\begin{tabular}{ccccc}
\hline Sample ID & Mass $(\mathbf{g})$ & $\begin{array}{c}\text { Volume } \\
\mathbf{( c m}^{\mathbf{3}} \mathbf{)}\end{array}$ & $\begin{array}{c}\text { Bulk Density } \\
\left(\mathbf{k g} / \mathbf{m}^{\mathbf{3}}\right)\end{array}$ & $\begin{array}{c}\text { Thermal } \\
\text { Conductivity } \boldsymbol{\lambda} \\
\mathbf{( W / m K )}\end{array}$ \\
\hline F50P & 612.3 & 619 & 989 & 0.1079 \\
F60P & 613.0 & 656 & 934 & 0.1029 \\
F70P & 511.5 & 647 & 791 & 0.0938 \\
\hline
\end{tabular}

As Table 5 shows, the higher the amount of fibres in the mix, the lower the bulk density and the thermal conductivity, as expected.

\section{Mechanical Properties}

The compressive and flexural tests on the mix have been performed at the Dipartimento di Ingegneria Civile, Ambientale, Aerospaziale, dei Materiali (DICAM) of the Università degli Studi di Palermo.

\subsection{Compressive Tests}

The compressive test consists of compressing a cylindrical sample, whose diameter/height ratio is $1 / 1$, between two plane surfaces with an increasing load. After cutting the samples to the required dimension, they were tested by means of a Zwick/Roell universal testing machine (Figure 3). The tests were performed with an upper crossbar speed of $2 \mathrm{~mm} / \mathrm{min}$.

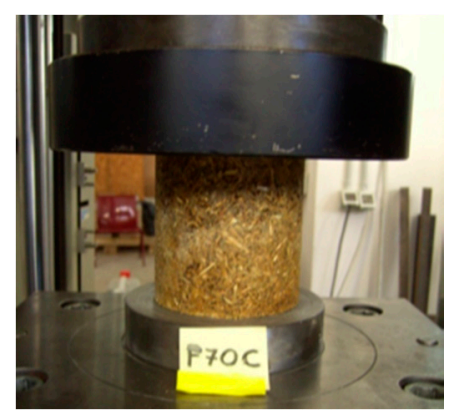

(a)

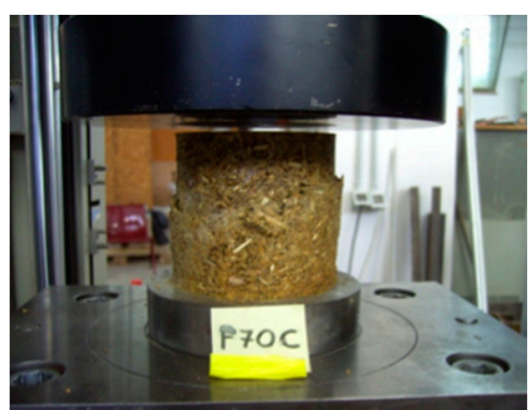

(b)

Figure 3. Compressive test performed on F70C sample: (a) before test; (b) after test.

The test ends when the sample crushes, resulting coupled values, compressive strength $(\mathrm{N}) /$ displacement $(\mathrm{mm})$. Dividing the compressive strength by the area of the samples, the stress $\sigma$ $\left(\mathrm{N} / \mathrm{mm}^{2}\right.$ or $\mathrm{MPa}$ ) was obtained, while dividing the displacement by the initial height of the sample, the strain $\varepsilon(\%)$ was obtained. Finally, the stress-strain curve $\sigma-\varepsilon$ has been reported for each sample. 
Sample F70C, even though visible damage occurred to the base, did not crush. The ultimate strength was equal to $5.82 \mathrm{MPa}$, while the Young modulus $E$, which is the slope of the $\sigma-\varepsilon$ curve in the elastic field, was equal to $413 \mathrm{MPa}$.

Sample F60C showed a considerable resistance, as it did not crush, remaining intact and compact. The ultimate strength was equal to $10.53 \mathrm{MPa}$, while the Young modulus $E$ was equal to $959.1 \mathrm{MPa}$.

Finally, sample F50C also showed a considerable resistance, remaining compact, with only some little fractures on the lateral surface. The ultimate strength was equal to $12.91 \mathrm{MPa}$, while the Young modulus $E$ was equal to $1003 \mathrm{MPa}$.

In Table 6, the results of the compressive test are reported.

Table 6. Physical characteristics of the cylindrical samples.

\begin{tabular}{|c|c|c|c|c|c|c|}
\hline Sample ID & $\begin{array}{c}\text { Dimension } \\
(\mathrm{D} / \mathrm{H}) \\
(\mathrm{mm} / \mathrm{mm})\end{array}$ & $\begin{array}{l}\text { Mass } \\
(\mathrm{g})\end{array}$ & $\begin{array}{c}\text { Volume } \\
\left(\mathrm{cm}^{3}\right)\end{array}$ & $\begin{array}{l}\text { Bulk Density } \\
\quad\left(\mathrm{kg} / \mathrm{m}^{3}\right)\end{array}$ & $\begin{array}{c}\text { Young } \\
\text { Modulus } E \\
\text { (MPa) }\end{array}$ & $\begin{array}{c}\text { Ultimate } \\
\text { Strength } \\
\text { (MPa) }\end{array}$ \\
\hline F70C & $100 / 100$ & 635 & 785 & 809 & 413 & 5.82 \\
\hline F60C & $100 / 100$ & 755 & 785 & 962 & 959.1 & 10.53 \\
\hline F50C & $100 / 100$ & 765 & 785 & 974 & 1003 & 12.91 \\
\hline
\end{tabular}

From Table 6, it can be observed that the higher the amount of fibres in the mix, the lower the bulk density, ultimate strength, and Young modulus.

In Figure 4 the stress-strain curve $\sigma-\varepsilon$ of the three samples tested are reported for comparison.

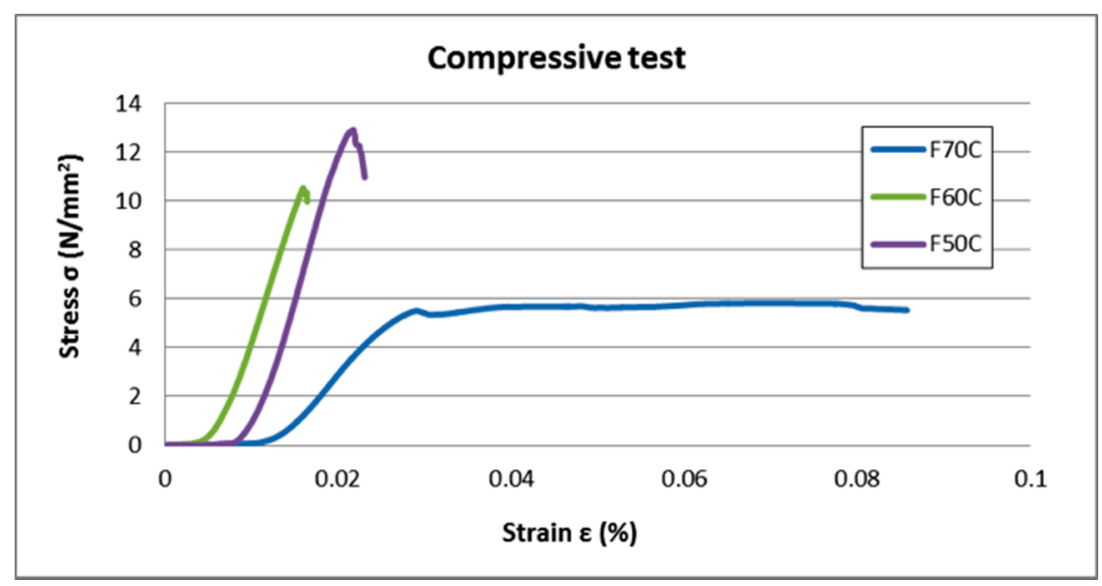

Figure 4. Stress-strain curve $\sigma-\varepsilon$ of the tested samples.

As shown in Figure 4, the $\sigma-\varepsilon$ curve trend for sample F70C is initially pseudo-horizontal, due to the opposition of the sample versus the external load, followed by an elastic branch and then by a sudden yielding of the material, representing the beginning of the plastic field, continuing until the material crushes. After the yielding point, the curve shows a monotonic weak decrease due to the ductile behaviour of the material, which can further displace in the post-elastic field.

Sample F60C and F50C show similar behaviour. The $\sigma-\varepsilon$ curve trend is initially pseudo-horizontal, followed by a linear branch in the plastic field until crushing. The curve is typical of brittle materials, lacking a plastic phase after the yielding point.

Sample F70C reaches high stress values, showing a high strain capacity after the elastic phase, with an increase in strain under constant stress. This characteristic of hay fibres that is conferred to the mix is particularly important, because it can contribute to the dissipation of energy in a building designed in a seismic zone. 
Samples with a lower amount of fibre have shown to be more resistant than sample F70C, but, conversely, have brittle behaviour without a plastic field.

The pseudo-horizontal tract of the $\sigma-\varepsilon$ curve is longer in samples with a higher fibre content, denoting a greater initial cohesion that hay fibres give once stressed.

Finally, the slope of the $\sigma-\varepsilon$ curve in the elastic field, which is tied to the stiffness of the material, is higher for samples with a lower fibre content.

\subsection{Three-Point Flexural Test}

The three-point flexural test was performed with the universal testing machine on the parallelepiped samples, previously used for thermal tests, after they have been cut into three stripes (Figure 5). These samples have been named with the same alphanumeric code of the starting sample, adding a letter $(\mathrm{A}, \mathrm{B}$, or $\mathrm{C})$ to distinguish them. Samples were put in the machine on the two supporting pins, taking care that the two extremities were symmetrically placed, as loading geometry and strain rate strongly influence the test. Furthermore, before the test started, a low preload was given to the sample by means of a rotating three-lever system placed at the base of the machine. Figure 6 shows some samples crushed after the flexural test.

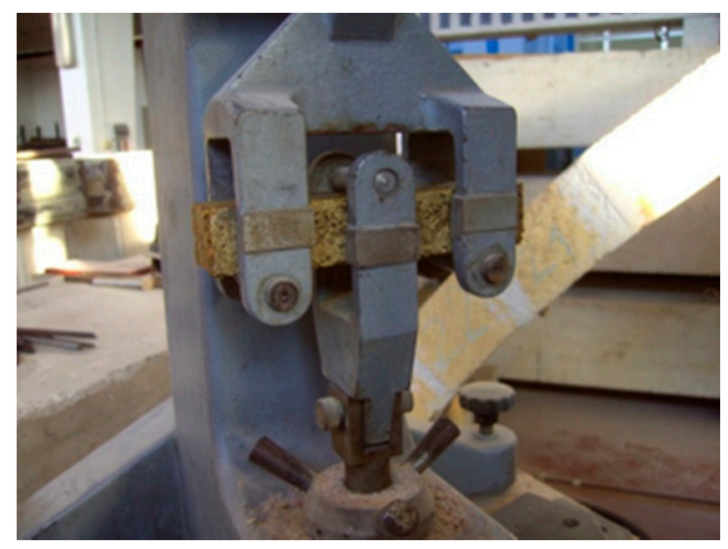

Figure 5. Three-point flexural test performed on a sample.

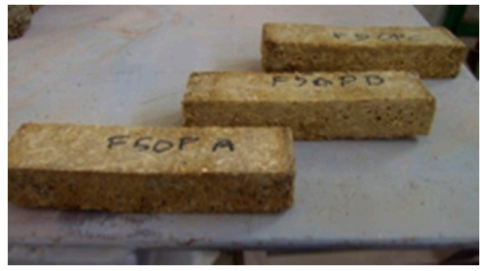

(a)

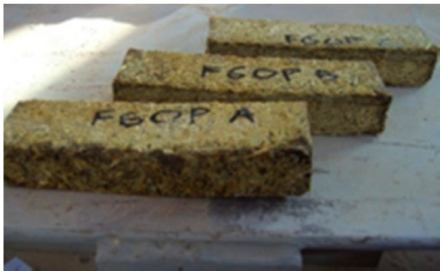

(b)

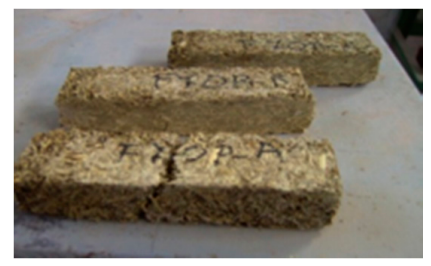

(c)

Figure 6. Samples crushed after the flexural test: (a) F50P samples; (b) F60P samples; (c) F70P samples.

In Table 7, ultimate load and ultimate strength values, calculated by means of the well-known Navier equation, are reported. For each mix, an average ultimate strength value is also reported. 
Table 7. Flexural test results.

\begin{tabular}{|c|c|c|c|c|c|c|c|}
\hline $\begin{array}{l}\text { Sample } \\
\text { ID }\end{array}$ & $\begin{array}{c}\text { Dimensions } \\
(\mathrm{L} \times \mathbf{P} \times \mathrm{H}) \\
(\mathrm{mm} \times \mathrm{mm} \times \mathrm{mm})\end{array}$ & $\begin{array}{c}\text { Mass } \\
\text { (g) }\end{array}$ & $\begin{array}{l}\text { Volume } \\
\left(\mathrm{cm}^{3}\right)\end{array}$ & $\begin{array}{c}\text { Bulk } \\
\text { Density } \\
\left(\mathrm{kg} / \mathrm{m}^{3}\right)\end{array}$ & $\begin{array}{l}\text { Ultimate } \\
\text { Load } \\
\text { (kg) }\end{array}$ & $\begin{array}{l}\text { Ultimate } \\
\text { Strength } \\
\text { (MPa) }\end{array}$ & $\begin{array}{c}\text { Average } \\
\text { Ultimate } \\
\text { Strength } \\
\text { (MPa) }\end{array}$ \\
\hline F50P.A & $159 \times 41 \times 28$ & 180 & 182 & 986 & 84.0 & 6.11 & \\
\hline F50P.B & $159 \times 41 \times 28$ & 180 & 182 & 986 & 72.5 & 5.28 & 6.00 \\
\hline F50P.C & $159 \times 41 \times 28$ & 180 & 182 & 986 & 91.0 & 6.62 & \\
\hline F60P.A & $160 \times 40 \times 29$ & 180 & 186 & 969 & 87.0 & 6.09 & \\
\hline F60P.B & $160 \times 40 \times 29$ & 180 & 186 & 969 & 89.0 & 6.23 & 6.04 \\
\hline F60P.C & $160 \times 40 \times 29$ & 180 & 186 & 969 & 83.0 & 5.81 & \\
\hline F70P.A & $158 \times 41 \times 29$ & 150 & 189 & 790 & 80.0 & 5.28 & \\
\hline F70P.B & $158 \times 40 \times 29$ & 145 & 185 & 783 & 104.0 & 7.04 & 6.11 \\
\hline F70P.C & $158 \times 41 \times 29$ & 150 & 189 & 790 & 91.0 & 6.01 & \\
\hline
\end{tabular}

From Table 7, it is clear that the ultimate strength is directly proportional to the ultimate load.

All hay-rosin samples showed a high cohesion during the flexural tests, a failure being indicated by a slight concave profile and the presence of more or less bended fractures near the tensile zone of the middle section of the sample.

\section{Discussions}

In this section, the performances of the biocomposite analysed in this work is compared with other work present in literature, from both a thermal and mechanical point of view.

The thermal conductivity values have been compared with the ones of another biocomposite, in which the vegetal fibres are hay, while the binder is lime (a mix of hydrated and hydraulic lime with a ratio of $4: 1$ ). The amount of fibre in the mix ranges from $16.6 \%$ to $33 \%$, with a granulometry from $4 \mathrm{~mm}$ to $8 \mathrm{~mm}$, and the bulk density of the samples ranges from $417 \mathrm{~kg} / \mathrm{m}^{3}$ to $718 \mathrm{~kg} / \mathrm{m}^{3}$, while the thermal conductivity ranges from $0.09179 \mathrm{~W} / \mathrm{mK}$ to $0.1534 \mathrm{~W} / \mathrm{mK}$ [71] (Figures 7 and 8).

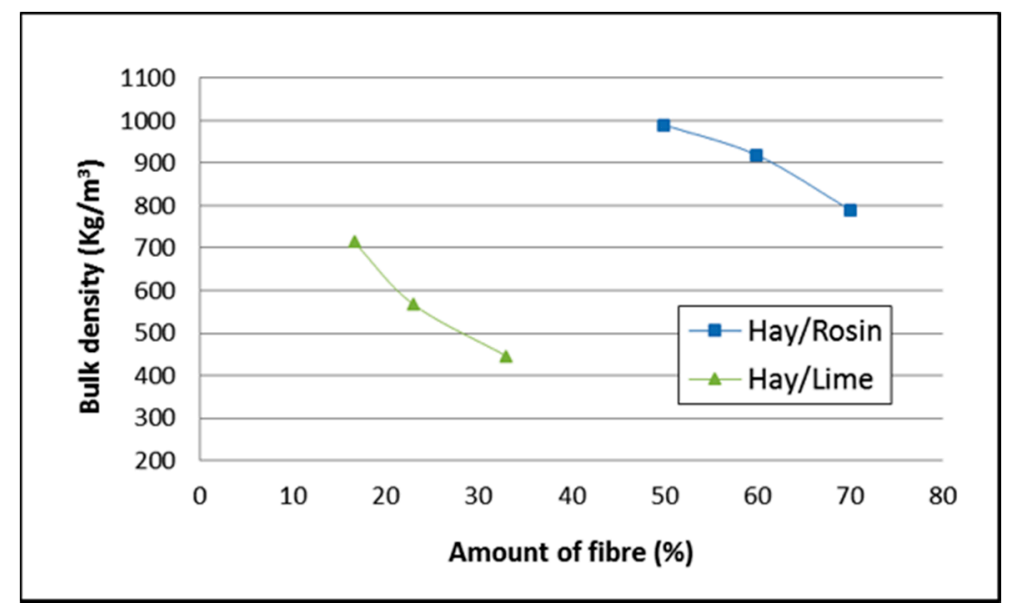

Figure 7. Comparison of the bulk density/amount of fibres (\%) trend for hay/rosin and hay/lime biocomposites.

From the comparison of the two materials, it is evident that the biocomposite hay/rosin, the object of the present work, presents higher bulk density and lower thermal conductivity values. This is probably due to the use of rosin as binder instead of lime, thus making it possible to increase the amount of fibres in the mix up to $70 \%$. On the other hand, when using lime, $40 \%$ fibre seems to be an upper limit, as the samples are very brittle and a further increase of fibres does not allow for the preparation of homogeneous mixes. 


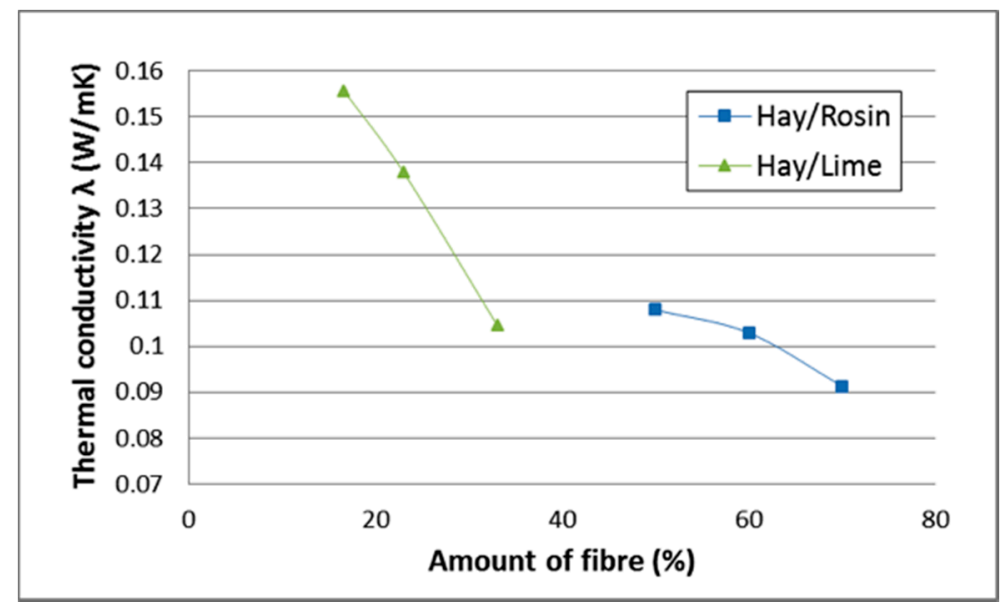

Figure 8. Comparison of the thermal conductivity/amount of fibres (\%) trend for hay/rosin and hay/lime biocomposites.

In Figure 9, the thermal conductivity/bulk density trend of the hay/rosin biocomposite is reported.

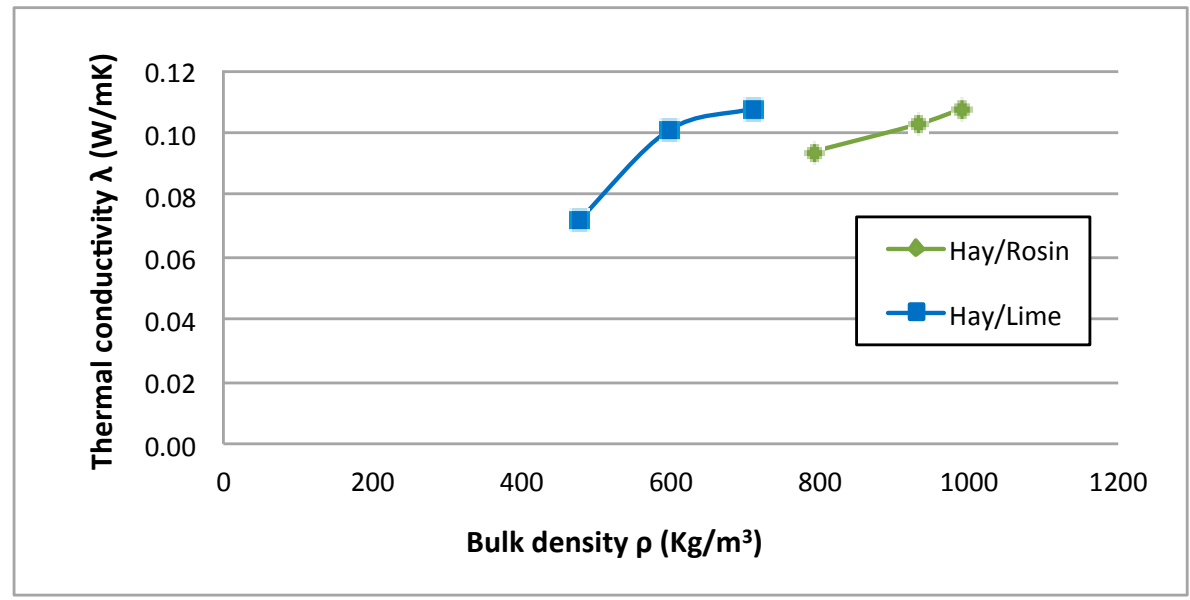

Figure 9. Thermal conductivity/bulk density trend of the hay/rosin biocomposite.

From Figure 9, the decrease of the thermal conductivity of the biocomposite is proportional to the decrease of its bulk density, the latter depending on the increase of fibres in the mix. However, there is physical upper limit to the amount of fibres that can be added to the mix, as, beyond a certain value, it is impossible to make it homogeneous.

With regard to the common insulation materials used in the building sector-like glass mineral wool, rock mineral wool, or polystyrene, which have thermal conductivities that range from $0.03 \mathrm{~W} / \mathrm{mK}$ to $0.04 \mathrm{~W} / \mathrm{mK}$ - the analysed mixtures have obviously higher values, but can still be considered as good insulation materials.

As far as the compressive tests are concerned, the maximum ultimate strength value of the hay/rosin biocomposite has been compared with the one of a hay/lime biocomposite [71] (16.7\% in weight of hay, chopped at $8 \mathrm{~mm}$ granulometry mixed with hydrated and hydraulic lime in a 1:4 ratio). The hay/rosin maximum ultimate strength, equal to $12.91 \mathrm{MPa}$, is considerably higher than the hay /lime ultimate strength (equal to $0.25 \mathrm{MPa}$ ) showing that the use of rosin as binder, instead of lime, strongly increases the compressive strength of the biocomposite (Table 8). 
Table 8. Comparison of the maximum ultimate strength of the two biocomposites with $8 \mathrm{~mm}$ granulometry.

\begin{tabular}{ccc}
\hline Biocomposite & $\begin{array}{c}\text { Fibres } \\
\mathbf{( \% )}\end{array}$ & $\begin{array}{c}\text { Ultimate Strength } \\
\mathbf{( M P a )}\end{array}$ \\
\hline Hay/Lime & 16.6 & 0.25 \\
F50C & 50.0 & 12.91 \\
\hline
\end{tabular}

As far as the flexural strength tests are concerned, the ultimate strength values of the hay/rosin biocomposite have been compared both with the ones of the already mentioned hay/lime biocomposite and other literature works concerning biocomposite made of natural fibres and resin. In particular, the biocomposites compared are the following:

A. Hay (70\% in weight) at $8 \mathrm{~mm}$ granulometry, $30 \%$ rosin, prepared applying an overpressure equal to $7.9 \mathrm{kPa}$ (present work). Ultimate strength equal to $6.00 \mathrm{MPa}$;

B. Hay (16.6\% in weight) at $8 \mathrm{~mm}$ granulometry, $16.7 \%$ hydrated lime, $66.7 \%$ hydraulic lime [71]. Ultimate strength equal to $0.25 \mathrm{MPa}$ [71];

C. Flax fibres ( $34 \%$ in weight) at $2 \mathrm{~mm}$ granulometry, with acrylated epoxidized soybean oil (AESO) mixed with styrene and divinylbenzene in the ratio $100: 45: 5$ by weight; furthermore, $1.5 \%$ in weight of an organic peroxide, USP-245, has been added to the resin. Samples realised by means of the resin transfer moulding (RTM) process (i.e., the closed mould containing the fibre mat has been filled with resin at $207 \mathrm{kPa}$, letting the resin in excess to flow out of the mould) [74]. Ultimate strength equal to $64 \mathrm{MPa}$;

D. Flax, cellulose, or recycled paper with AESO mixed with styrene in 2:1 weight ratio, then added with cumyl peroxide ( $3 \%$ in weight) and cobalt naphthenate ( $0.8 \%$ in weight). Resin is infused in the fibre mat by means of the vacuum resin transfer moulding (VARTM) process [75]. Ultimate strength ranging from $27 \mathrm{MPa}$ to $60 \mathrm{MPa}$;

E. Pineapple leaf fibres at $1 \mathrm{~mm}$ granulometry ( $30 \%$ in weight), with poly (hydroxybutyrate-cohydroxyvalerate), a biodegradable organic polymer commonly named PHBV. A $1 \mathrm{~mm}$ thickness laminate has been prepared by sandwiching three layers of fibres between four layers of PHBV films. The three fibre layers were arranged in $0^{\circ} / 90^{\circ} / 0^{\circ}$ directions with $25 \%$ of the fibre weight in the top and bottom layers each, and the remaining 50\% in the middle layer. The mould was then heated at $180^{\circ} \mathrm{C}$ and the sample pressed at $140 \mathrm{MPa}$ [76]. Ultimate strength equal to $86 \mathrm{MPa}$;

F. Manila hemp fibres ( $70 \%$ in weight) with a starch-based emulsion-type biodegradable resin containing fine particles of approximately $4.6 \mu \mathrm{m}$ in diameter, suspended in aqueous solution, with a mass content of $40 \%$. Samples have been hot-pressed $\left(130^{\circ} \mathrm{C}\right)$ at $10 \mathrm{MPa}$ for $10 \mathrm{~min}$ [77]. Ultimate strength equal to $223 \mathrm{MPa}$.

From the values above-reported, it is once more evident that the use of a resin as binder in the biocomposite, instead of lime, strongly increases its mechanical properties. In particular, the hay/rosin biocomposite shows the lowest flexural strength values amongst the other biocomposite using resin as binder. However, it has to be pointed out that all these biocomposites have been obtained by means of high-pressure values in the preparation processes, ranging from $0.2 \mathrm{MPa}$ to $140 \mathrm{MPa}$, while the biocomposite analysed in the present work only received an overpressure equal to $7.9 \mathrm{kPa}$. The increase of the overpressure received by the sample obviously increases its bulk density and, thus, its mechanical resistance, at the expense of the thermal conductivity, as shown in Figure 9. However, all the cited works only focus on the mechanical properties of the biocomposites, while the thermal conductivity has not been measured. 


\section{Conclusions}

In this paper, an analysis of the thermal and mechanical properties of a biocomposite has been carried out. The choice of the mix has fallen on two natural materials that are cheap and/or widespread throughout Europe, hay and rosin, with the percentage of fibres ranging from $50 \%$ to $70 \%$ in weight.

The thermal and mechanical tests performed on the samples have shown very promising results. In particular, the thermal tests have shown a thermal conductivity ranging from 0.08535 to $0.1079 \mathrm{~W} / \mathrm{mK}$, values that indicate good thermal insulation properties of the biocomposite. The thermal conductivity is clearly dependent on the amount of fibres in the mix, with a greater percentage of fibres resulting in lower density and thermal conductivity.

As far as the mechanical properties are concerned, the tests have shown a maximum ultimate strength ranging from 5.82 to $12.91 \mathrm{MPa}$ and a flexural strength nearly constant, equal to $6.00 \mathrm{MPa}$. Samples with a smaller amount of fibres have proven to be more resistant, but, conversely, have a more brittle behaviour, as indicated by the lack of a plastic behaviour in the $\sigma-\varepsilon$ curve.

The mechanical tests performed on the biocomposite, compared with a mix of lime and hay, have shown that the substitution of lime with resin as binder strongly increases the mechanical properties of the biocomposite.

Further analyses have to be performed in order to improve both the thermal and mechanical properties of the biocomposite. In this regard, an in-depth study on the preparation of the mix is currently ongoing. In more detail, the influence of the amount and granulometry of shives in the mixture, the pressure applied when filling the mould, and the effects of the duration and modality of the drying process on the mechanical properties of the biocomposite are being investigated. Moreover, we are planning an experimental campaign in order to evaluate the durability and the response to the environmental factors of the biocomposite.

Author Contributions: Maria La Gennusa, Joan Rieradevall and Gianluca Scaccianoce conceived of and designed the research; Joan Rieradevall generally supervised the research group; Maria La Gennusa and Giancarlo Sorrentino performed the experiments and carried out measures at the Laboratory for Indoor Environments and Sustainable Technologies; Pere Llorach-Massana, Juan Ignacio Montero, Francisco Javier Peña and Giancarlo Sorrentino collected and processed the data; Maria La Gennusa, Joan Rieradevall and Gianluca Scaccianoce interpreted and analyzed the data; Patrizia Ferrante and Maria La Gennusa wrote the paper. All authors have revised the article critically and approved the final manuscript.

Conflicts of Interest: The authors declare no conflict of interest.

\section{References}

1. European Parliament and the Council. Directive 2010/31/EU of the European Parliament and of the Council of 19 May 2010 on the Energy Performance of Buildings (Recast). Available online: https:/ / www.me.government.bg/en/library/directive-2010-31-eu-of-the-european-parliament-and-ofthe-council-of-19-may-2010-on-the-energy-perf-171-c80-m262-1.html (accessed on 22 February 2017).

2. Korjenic, A.; Petránek, V.; Zach, J.; Hroudová, J. Development and performance evaluation of natural thermal-insulation materials composed of renewable resources. Energy Build. 2011, 43, 2518-2523. [CrossRef]

3. Singh, B.; Gupta, M.; Tarannum, H. Jute sandwich composite panels for building applications. J. Biobased Mater. Bioenergy 2010, 4, 397-407. [CrossRef]

4. Cosereanu, C.; Lazarescu, C.; Curtu, I.; Lica, D.; Sova, D.; Brenci, L.M.; Stanciu, M.D. Research on new structures to replace polystyrene used for thermal insulation of buildings. Mater. Plast. 2010, 47, 341-345.

5. Silva, S.P.; Sabino, M.A.; Fernandas, E.M.; Correlo, V.M.; Boesel, L.F.; Reis, R.L. Cork. Properties, capabilities and applications. Int. Mater. Rev. 2005, 50, 345-365.

6. Pinto, J.; Cruz, D.; Paiva, A.; Pereira, S.; Tavares, P.; Fernandes, L.; Varum, H. Characterization of corn cob as a possible raw building material. Constr. Build. Mater. 2012, 34, 28-33. [CrossRef]

7. Paivaa, A.; Pereiraa, S.; Sá, A.; Cruz, D.; Varum, H.; Pinto, J. A contribution to the thermal insulation performance characterization of corn cob particleboards. Energy Build. 2012, 45, 274-279. [CrossRef]

8. Kodah, Z.H.; Jarrah, M.A.; Shanshal, N.S. Thermal characterization of foam-cane (Quseab) as an insulant material. Energy Convers. Manag. 1999, 40, 349-367. [CrossRef] 
9. Manohar, K.; Ramroopsingh, J.; Yarbrough, D.W. Use of sugarcane fiber as building insulation. Am. Soc. Test. Mater. 2002, 1426, 299-313.

10. Ren, Q.; Li, J.Z.; Lu, Z.Y. Studies on the wood fiber-rock wool composites. Beijing Linye Daxue Xuebao/J. Beijing For. Univ. 2007, 29, 161-164.

11. Nicolajsen, A. Thermal transmittance of a cellulose loose-fill insulation material. Build. Environ. 2005, 40, 907-914. [CrossRef]

12. Lazko, J.; Dupré, B.; Dheilly, R.M.; Quéneudec, M. Biocomposites based on flax short fibres and linseed oil. Ind. Crops Prod. 2011, 33, 317-324. [CrossRef]

13. Dalmay, P.; Smith, A.; Chotard, T.; Sahay-Turner, P.; Gloaguen, V.; Krausz, P. Properties of cellulosic fibre reinforced plaster: Influence of hemp or flax fibres on the properties of set gypsum. J. Mater. Sci. 2010, 45, 793-803. [CrossRef]

14. Svennerstedt, B. Advantages of recycled \& renewable materials for structural and insulation applications. Nonwovens World Mag. 2005, 14, 39-48.

15. Kymäläinen, H.R.; Sjöberg, A.M. Flax and hemp fibres as raw materials for thermal insulations. Build. Environ. 2008, 43, 1261-1269. [CrossRef]

16. Ashour, T.; Georg, H.; Wu, W. Performance of straw bale wall: A case of study. Energy Build. 2011, 43, 1960-1967. [CrossRef]

17. Ashour, T.; Wieland, H.; Georg, H.; Bockisch, F.J.; Wu, W. The influence of natural reinforcement fibres on insulation values of earth plaster for straw bale buildings. Mater. Des. 2010, 31, 4676-4685. [CrossRef]

18. Goodhew, S.; Carfrae, J.; De Wilde, P. Briefing. Challenges related to straw bale construction. Proceedings of the Institution of Civil Engineers. Eng. Sustain. 2010, 163, 185-189.

19. Khedari, J.; Charoenvai, S.; Hirunlabh, J. New insulating particleboards from durian peel and coconut coir. Build. Environ. 2003, 38, 435-441. [CrossRef]

20. Asasutjarit, C.; Hirunlabh, J.; Khedari, J.; Charoenvai, S.; Zeghmati, B.; Shin, U.C. Development of coconut coir-based lightweight cement board. Constr. Build. Mater. 2007, 21, 277-288. [CrossRef]

21. Etuk, S.E.; Akpabio, L.E.; Akpabio, K.E. Determination of thermal properties of Cocos Nucifera trunk for predicting temperature variation with its thickness. Arabian J. Sci. Eng. 2005, 30, 121-126.

22. Kochhar, G.S.; Manohar, K. Use of coconut fiber as a low-cost thermal insulator. In Insulation Materials: Testing and Applications; Graves, Z., Ed.; ASTM: West Conshohocken, PA, USA, 1997; Volume 3, pp. $283-291$.

23. Elfordy, S.; Lucas, F.; Tancret, F.; Scudeller, Y.; Goudet, L. Mechanical and thermal properties of lime and hemp concrete ("hempcrete") manufactured by a projection process. Constr. Build. Mater. 2008, 22, 2116-2123. [CrossRef]

24. Arnaud, L.; Gourlay, E. Experimental study of parameters influencing mechanical properties of hemp concrete. Constr. Build. Mater. 2012, 28, 50-56. [CrossRef]

25. Tran Le, A.D.; Maalouf, C.; Mai, T.H.; Wurtz, E.; Collet, F. Transient hygrothermal behaviour of a hemp concrete building envelope. Energy Build. 2010, 42, 1797-1806. [CrossRef]

26. Colinart, T.; Glouannec, P.; Chauvelon, P. Influence of the setting process and the formulation on the drying of hemp concrete. Constr. Build. Mater. 2012, 30, 372-380. [CrossRef]

27. Asprone, D.; Durante, M.; Prota, A.; Manfredi, G. Potential of structural pozzolanic matrix-hemp fiber grid composites. Constr. Build. Mater. 2011, 25, 2867-2874. [CrossRef]

28. Benfratello, S.; Capitano, C.; Peri, G.; Rizzo, G.; Scaccianoce, G.; Sorrentino, G. Thermal and structural properties of a hemp-lime biocomposite. Constr. Build. Mater. 2013, 48, 745-754. [CrossRef]

29. Pappu, A.; Patil, V.; Jain, S.; Mahindrakar, A.; Haque, R.; Thakur, V.K. Advances in industrial prospective of cellulosic macromolecules enriched banana biofibre resources: A review. Int. J. Biol. Macromol. 2015, 79, 449-458. [CrossRef] [PubMed]

30. Pappu, A.; Saxena, M.; Thakur, V.K.; Sharma, A.; Haque, R. Facile extraction, processing and characterization of biorenewable sisal fibers for multifunctional applications. J. Macromol. Sci. Part A 2016, 53, 424-432. [CrossRef]

31. Thakur, V.K.; Thakur, M.K. Processing and characterization of natural cellulose fibers/thermoset polymer composites. Carbohydr. Polym. 2014, 109, 102-117. [CrossRef] [PubMed]

32. Thakur, V.K.; Thakur, M.K.; Gupta, R.K. Review: Raw Natural Fiber-Based Polymer Composites. Int. J. Polym. Anal. Charact. 2014, 19, 256-271. [CrossRef] 
33. Brahim, S.B.; Cheikh, R.B. Influence of fibre orientation and volume fraction on the tensile properties of unidirectional Alfa-polyester composite. Compos. Sci. Technol. 2007, 67, 140-147. [CrossRef]

34. Felline, F.; Pappada, S.; Gennaro, R.; Passaro, A. Resin transfer moulding of composite panels with bio-based resins. SAMPE J. 2013, 49, 20-24.

35. Feldmann, M.; Bledzki, A.K. Bio-based polyamides reinforced with cellulosic fibres-Processing and properties. Compos. Sci. Technol. 2014, 100, 113-120. [CrossRef]

36. Fink, H.P.; Ganster, J. Novel thermoplastic composites from commodity polymers and man-made cellulose fibers. Macromol. Symp. 2006, 244, 107-118. [CrossRef]

37. Oksman, K. High quality flax fibre composites manufactured by the resin transfer moulding process. J. Reinf. Plast. Compos. 2001, 20, 621-627. [CrossRef]

38. Phillips, S.; Baets, J.; Lessard, L.; Hubert, P.; Verpoest, I. Characterization of flax/epoxy prepregs before and after cure. J. Reinf. Plast. Compos. 2013, 32, 777-785. [CrossRef]

39. Graupner, N.; Mussig, J. A comparison of the mechanical characteristics of kenaf and lyocell fibre reinforced poly(lactic acid) (PLA) and poly(3-hydroxybutyrate) (PHB) composites. Compos. Part A 2011, 42, 2010-2019. [CrossRef]

40. Newman, R.H.; Le Guen, M.J.; Battley, M.A.; Carpenter, J.E.P. Failure mechanisms in composites reinforced with unidirectional Phormium leaf fibre. Compos. Part A 2010, 41, 353-359. [CrossRef]

41. Oksman, K.; Wallstrom, L.; Berglund, L.A.; Toledo, R.D. Morphology and mechanical properties of unidirectional sisal-epoxy composites. J. Appl. Polym. Sci. 2002, 84, 2358-2365. [CrossRef]

42. Islam, M.S.; Pickering, K.L.; Foreman, N.J. Influence of alkali fiber treatment and fiber processing on the mechanical properties of hemp/epoxy composites. J. Appl. Polym. Sci. 2011, 119, 3696-3707. [CrossRef]

43. Zhang, L.; Miao, M. Commingled natural fibre/polypropylene wrap spun yarns for structured thermoplastic composites. Compos. Sci. Technol. 2010, 70, 130-135. [CrossRef]

44. Goutianos, S.; Peijs, T.; Nystrom, B.; Skrifvars, M. Development of flax fibre based textile reinforcements for composite applications. Appl. Compos. Mater. 2006, 13, 199-215. [CrossRef]

45. Oksman, K. Mechanical properties of natural fibre mat reinforced thermoplastic. Appl. Compos. Mater. 2000, 7, 403-414. [CrossRef]

46. Ochi, S. Mechanical properties of kenaf fibers and kenaf/PLA composites. Mech. Mater. 2008, 40, 446-452. [CrossRef]

47. Baghaei, B.; Skrifvars, M.; Berglin, L. Manufacture and characterisation of thermoplastic composites made from PLA/hemp co-wrapped hybrid yarn prepregs. Compos. Part A 2013, 50, 93-101. [CrossRef]

48. Van de Weyenberg, I.; Ivens, J.; De Coster, A.; Kino, B.; Baetens, E.; Verpoest, I. Influence of processing and chemical treatment of flax fibres on their composites. Compos. Sci. Technol. 2003, 63, 1241-1246. [CrossRef]

49. Le Guen, M.J.; Newman, R.H. Pulped Phormium tenax leaf fibres as reinforcement for epoxy composites. Compos. Part A 2007, 38, 2109-2115. [CrossRef]

50. Li, H.J.; Sain, M.M. High stiffness natural fiber-reinforced hybrid polypropylene composites. Polym. Plast. Technol. Eng. 2003, 42, 853-862. [CrossRef]

51. Snijder, M.H.B.; Bos, H.L. Reinforcement of polypropylene by annual plant fibers: Optimisation of the coupling agent efficiency. Compos. Interfaces 2000, 7, 69-79. [CrossRef]

52. Rana, A.K.; Mandal, A.; Mitra, B.C.; Jacobson, R.; Rowell, R.; Banerjee, A.N. Short jute fiber-reinforced polypropylene composites: Effect of compatibilizer. J. Appl. Polym. Sci. 1998, 69, 329-338. [CrossRef]

53. Sain, M.; Suhara, P.; Law, S.; Bouilloux, A. Interface modification and mechanical properties of natural fiber-polyolefin composite products. J. Reinf. Plast. Compos. 2005, 24, 121-130. [CrossRef]

54. Zampaloni, M.; Pourboghrat, F.; Yankovich, S.; Rodgers, B.; Moore, J.; Drzal, L.; Mohanty, A.K.; Misra, M. Kenaf natural fiber reinforced polypropylene composites: A discussion on manufacturing problems and solutions. Compos. Part A 2007, 38, 1569-1580. [CrossRef]

55. Hu, R.; Lim, J.K. Fabrication and mechanical properties of completely biodegradable hemp fiber reinforced polylactic acid composites. J. Compos. Mater. 2007, 41, 1655-1669. [CrossRef]

56. Baghaei, B.; Skrifvars, M.; Salehi, M.; Bashir, T.; Rissanen, M.; Nousiainen, P. Novel aligned hemp fibre reinforcement for structural biocomposites: Porosity, water absorption, mechanical performances and viscoelastic behaviour. Compos. Part A 2014, 61, 1-12. [CrossRef]

57. Hughes, M.; Carpenter, J.; Hill, C. Deformation and fracture behaviour of flax fibre reinforced thermosetting polymer matrix composites. J. Mater. Sci. 2007, 42, 2499-2511. [CrossRef] 
58. Angelov, I.; Wiedmer, S.; Evstatiev, M.; Friedrich, K.; Mennig, G. Pultrusion of a flax/polypropylene yarn. Compos. Part A 2007, 38, 1431-1438. [CrossRef]

59. Rodriguez, E.; Petrucci, R.; Puglia, D.; Kenny, J.M.; Vazquez, A. Characterization of composites based on natural and glass fibers obtained by vacuum infusion. J. Compos. Mater. 2005, 39, 265-282. [CrossRef]

60. Bodros, E.; Pillin, I.; Montrelay, N.; Baley, C. Could biopolymers reinforced by randomly scattered flax fibre be used in structural applications? Compos. Sci. Technol. 2007, 67, 462-470. [CrossRef]

61. Herrmann, A.S.; Nickel, J.; Riedel, U. Construction materials based upon biologically renewable resources-From components to finished parts. Polym. Degrad. Stab. 1998, 59, 251-261. [CrossRef]

62. Van de Velde, K.; Kiekens, P. Effect of material and process parameters on the mechanical properties of unidirectional and multidirectional flax/polypropylene composites. Compos. Struct. 2003, 62, 443-448. [CrossRef]

63. Carpenter, J.E.P.; Miao, M.; Brorens, P. Deformation behaviour of composites reinforced with four different linen flax yarn structures. In Advanced Materials and Processing IV; Trans Tech Publications: Stafa-Zurich, Switzerland, 2007; pp. 263-266.

64. Bledzki, A.K.; Mamun, A.A.; Lucka, M.; Gutowsk, V.S. The effects of acetylation on properties of flax fibre and its polypropylene composites. Express Polym. Lett. 2008, 2, 413-422. [CrossRef]

65. Le, M.T.; Pickering, K.L. The potential of harakeke fibre as reinforcement in polymer matrix composites including modelling of long harakeke fibre composite strength. Compos. Part A 2015, 76, 44-53. [CrossRef]

66. Madsen, B.; Lilholt, H. Physical and mechanical properties of unidirectional plant fibre composites-An evaluation of the influence of porosity. Compos. Sci. Technol. 2003, 63, 1265-1272. [CrossRef]

67. Islam, M.S.; Pickering, K.L.; Foreman, N.J. Influence of alkali treatment on the interfacial and physico-mechanical properties of industrial hemp fibre reinforced polylactic acid composites. Compos. Part $A$ 2010, 41, 596-603. [CrossRef]

68. Devi, L.U.; Bhagawan, S.S.; Thomas, S. Mechanical properties of pineapple leaf fiber-reinforced polyester composites. J. Appl. Polym. Sci. 1997, 64, 1739-1748. [CrossRef]

69. Rong, M.Z.; Zhang, M.Q.; Liu, Y.; Yang, G.C.; Zeng, H.M. The effect of fiber treatment on the mechanical properties of unidirectional sisal-reinforced epoxy composites. Compos. Sci. Technol. 2001, 61, 1437-1447. [CrossRef]

70. Pickering, K.L.; Aruan Efendy, M.G.; Le, T.M. A review of recent developments in natural fibre composites and their mechanical performance. Compos. Part A 2016, 83, 98-112. [CrossRef]

71. Giarratana, L. Materiali Naturali-Caratterizzazione Termica di Alcune fibre Naturali per L'isolamento Degli Edifici. Master's Thesis, Università degli studi di Palermo, Palermo, Italy, July 2011.

72. Petersen, J.M. Physical properties of wood rosin. Ind. Eng. Chem. 1932, 24, 168-173. [CrossRef]

73. EN 12667. Thermal Performance of Building Materials and Products_Determination of Thermal Resistance by Means of Guarded Hot Plate and Heat Flow Meter Methods-Products of High and Medium Thermal Resistance; British Standards Institution: London, UK, 2001.

74. Williams, G.I.; Wool, R.P. Composites from Natural Fibers and Soy Oil Resins. Appl. Compos. Mater. 2000, 7, 421-432. [CrossRef]

75. O'Donnell, A.; Dweib, M.A.; Wood, R. Natural fiber composites with plant oil-based resin. Compos. Sci. Technol. 2004, 64, 1135-1145.

76. Luo, S.; Netravali, A.N. Interfacial and mechanical properties of environment-friendly "green" composites made from pineapple fibers and poly(hydroxybutyrate-co-valerate) resin. USA J. Mater. Sci. 1999, 34, 3709-3719. [CrossRef]

77. Ochi, S. Development of high strength biodegradable composites using Manila hemp fiber and starch-based biodegradable resin. Compos. Part A 2006, 37, 1879-1883. [CrossRef]

(C) 2017 by the authors. Licensee MDPI, Basel, Switzerland. This article is an open access article distributed under the terms and conditions of the Creative Commons Attribution (CC BY) license (http:/ / creativecommons.org/licenses/by/4.0/). 